\title{
Enhancing Employability Skills Through Infosys Campus Connect Programme: A Case Study
}

\author{
Balasubramani $\mathbf{R}^{1}$, Devidas ${ }^{2}$ \\ ${ }^{1}$ Professor \& Head, ${ }^{2}$ Assistant Professor \\ ${ }^{1,2}$ Dept. of ISE, \\ ${ }^{1,2}$ NMAM Institute of Technology, Nitte \\ 'balasubramani.r@nitte.edu.in,'2devidasbhat@nitte.edu.in
}

\begin{abstract}
Enhancing the employability skills of the graduates is the need of the hour for every engineering education institute. To improve the employability skills, every institute follows their own method. Providing soft skills \& technical skills training, arranging lectures by industry $\&$ academic experts, training students for global certifications etc. are few of the methods. In this paper, we discuss our institute's association with Infosys through their Campus Connect Programme, which has immensely benefited out students to become industry ready. Also, we discuss the ways how Infosys addresses the requirements of faculty and students. We strongly believe that effective implementation of Infosys Campus Connect programme will bridge the gap between our academic outputs and the industry requirements.
\end{abstract}

Keywords - Employability skills, Infosys Campus Connect, Industry Ready

\section{Balasubramani R}

Professor \& Head,

Dept. of ISE, Dept. of ISE, NMAM Institute of Technology, Nitte balasubramani.r@nitte.edu.in

\section{Introduction}

Each year, India as a country produces the second largest number ofengineering graduates in the world.At one time, there were only a handful of engineering institutes butnow the number of institutes set up for various disciplines year on yearindicates an engineering education boom in India. Engineering collegesin the country have been growing at 20 per cent a year. Further thequality of engineering education is also getting a boost.The paradox is that, despite the increase in the number of colleges, thecompetition for acquiring fresh talent every year is so heated that itgives an impression that resources are really scarce. In reality, there is aplethora of career options for engineers of current years. Thechallenge is not the supply of talent but that of talent that meets theneeds of the corporate world. In other words, the challenge is that ofemployability! It is not about having a good curriculum or good faculty. What then is the employability enigma? It has been found that if the students augment their skills in a fewspecific areas desired by the industry, employability in the country canbe significantly enhanced. Here the industries come into picture to collaborate with academic in designing, developing and delivering the curricula as per their needs. In this paper, we discuss different implementation methodologies followed by Infosys through their Campus Connect Programme.

\section{Infosys Campus Connect}

As a primary stakeholder in creating a vibrant 
talent pool of future engineering graduates, Infosys launched Campus Connect(CC) [1], in May 2004, a first of its kind IndustryAcademia interaction program. CC aims to be a forum where some of the best practices at Infosys can be shared with institutions. CC also looks at aligning the needs ofinstitutions, its faculty and students, with those of the IT industry.

The main objective of $\mathrm{CC}$ is to evolve a model through which Infosys and academia

u Can partner for competitiveness

u Can enhance the pool of highly capable talent for growth requirements in the IT space

u Can enhance the quality of IT education

$\mathrm{CC}$ equips students not only in computer science and software engineering, but also helps them apply their learning to practical situations, with special emphasis on teamwork, project management, cross functional networking and effective communication.Several components are weaved together for effective, fastpaced learning: Conclaves, Road Shows at Institution Campuses, Faculty Enablement Programs, Industrial Visits for Students and Faculty, Foundation Program Rollout, Seminars and Workshops on Campuses, Programming Contests for Students, Sabbaticals, Technical Events and Research Paper Sponsorships, Soft skills for students and faculty.

As on Dec. 2014, about323,068students and 11,714Faculty members have been benefited by CC. Infosysis working with over 100 autonomous engineering institutions across the country to cocreate and Co-Teach industry electivesin the areas of foundational Computer Science, advanced topicslike, Business Intelligence, Building Enterprise Applications, Mobile Application Developmentand Soft Skills.

Industry aligned elective course

1. Essentials of Information Technology

2. Business Intelligence

3. Enterprise Applications

4. Mainframe Technology

5. Aerospace Engineering

6. Web Technologies

7. Mobile Application Development

8. C\# and .NET Technologies
9. Web 2.0 Programming and Web Services 10. Soft Skills

\section{Inspire - The Campus Connect Faculty Partnership Model}

\section{A. Rationale for the Program}

Faculty members play a vital role in in this collaboration between industry and academia and hence it becomes imperative to strengthen the bond with them [1]. The rationale behind Inspire is to enhance our primary partnership model with faculty in such a way where:

1. The faculty is not only recognized by way of certification and awards but they also see a 'Growth Path' with Infosys

2. Recognition and rewards are aligned to their contribution

3. Competency development offerings from Infosys are also aligned to respective contribution of faculty

\section{B. Inspire - Faculty Partnership Model}

Inspire serves as a platform to boost the partnership between Infosys and faculty members of Campus Connect partnering institutions. Inspire encourages effective collaboration and continuous learning to enhance quality in education. Inspire is also a celebration of excellence where the faculty members will get recognized and rewarded for their outstanding contributions to Campus Connect programs and events. Additionally "Inspire" inspires by way of Awareness, Education, Engagement and Recognition to promote holistic learning. This visibility and recognition across the industry and academia will encourage the rest of the community to achieve greater effectiveness and results in turn. In addition to the flavour of recognition, Inspire will also provide an opportunity for the Campus Connect faculty community to visualize and accomplish a 'Growth-Path' with Infosys in terms of contributions to Campus Connect, thereby strengthening the mutual relationship and in the process avail more competency development offerings from Infosys.

C. Objectives of Inspire

Short Term 
1. Recognition of faculty contribution and excellence

2. Enhance faculty motivation to participate in Campus Connect offerings

3. Provide faculty a potential growth path in terms of contribution to Campus Connect

Medium Term

1. Create a push pull factor with faculty

2. Provide recognition and rewards aligned with their contribution

Long Term

1. Competency Development of faculty

2. Sustainable relationship with faculty

3. Model for Aligned faculty offerings

Inspire Model for Partnership can be seen as a blend of recognizing faculty excellence and a platform for exercising their skills in a unique manner. The entire framework can be divided into the following three sections:

\section{1) Faculty Credit Point Framework}

Faculty members can earn credit points as they get involved in or contribute to CC program roll-out at their respective institutions. The two categories from which credit points can be earned are:

Course Delivery (CC Foundation Program, Soft Skills or Industry Electives)

Event Participation / Contribution to CC Offerings (Includes FEPs, Soft Skills Workshops, Peer Enablement Programs, Webinars / Seminars and so on)

This scheme will be kept open throughout the calendar year (from January - December) in CC Portal. All registered faculty members can maintain their Credit Point account in the portal where they can record their contributions in various categories. Credit Points will be calculated implicitly by the portal system based on pre-defined mappings. This framework is developed from a holistic perspective so that it covers primary performance and contribution categories of faculty members with respect to Campus Connect program. The scheme, since it is kept open throughout the year, provides flexibility and transparency for faculty members to plan their course of action to earn credit points.

At the end of a year (i.e. after end of December), concerned faculty members are expected to complete their submissions. The credit point account for that year gets frozen and final credit points will be assigned to them. This finalization will be subject to approval from the respective CC College SPoC and verification by CC DC SPoC.

Subsequently, based on the number of credit points bagged by faculty members, they will be segmented into the following three levels:

Bronze Partner

Silver Partner

Gold Partner

2) Infosys Campus Connect Faculty Excellence Awards

Campus Connect Excellence Certificates based on levels will be awarded to the faculty members during an annual event held at Infosys DCs. This event, typically, will be conducted between April/May, where the recognition will be done for the faculty contribution during the previous year. All the eligible faculty members who have qualified for any of the levels (Bronze, Silver or Gold) will be invited to Infosys DC for this event.

The annual event will provide an opportunity for the identified faculty members to showcase the unique work / deliverables / practices which they have demonstrated or created. There will be a few live onstage events on the day in Technical tracks and winners would be rewarded. The winners would also be invited for delivering webinars anchored by Infosys.

Technical track includes the two following live events:

\section{a) Content Guru}

The participating faculty members need to submit any artifacts which they have created and deployed in order to enhance the course delivery and student learning effectiveness. The artifacts that may be created and submitted can include the following.

Case Studies that model a real world scenario based on topics / focus areas from any of the Foundation Program 3.1 or Campus Connect elective courses and their suggested solution(s) 
Integrated Projects that involves the application of concepts from Foundation Program 3.1 courses and which involves creation of Project Deliverables (viz. SRS, Design Documents and Test Plans) based on industry followed standards in SDLC

CAMP Based Assessment Question Bank that emphasizes the importance of assessments in effective learning process. Here the participants can submit a Question Bank based on the courses in Foundation Program 3.1 package and that adheres to the Campus Connect CAMP model with majority of Analytical and Practice Based questions

Any other artifacts that have been created and used for course delivery, which has helped the faculty to enhance course delivery and student learning effectiveness

Content Guru is designed to reinforce:

Application, analysis and synthesize of technical knowledge to model and solve real world challenges

Practicing of industry standards and benchmarks in Project Development and Assessment Methodology

\section{b) Distinguished Facilitator}

The participating faculty members are expected to make a live presentation in front of Infosys jury, demonstrating novel and innovative facilitation techniques during course delivery resulting in better student learning effectiveness in class room. This presentation can include:

a. Learning Activities (Individual / Team)

b. Innovative assessments

c. Leveraging Technology

Distinguished Facilitator event is designed to bringout:

unique strengths of facilitators

a platform to encourage constructive feedback to improve effectiveness

\section{3) Alignment of Competency Development Offerings}

The relevance of this partnership model is further enhanced by aligning the CC Program offerings (existing and new) with the different partnership levels. Given below is the mapping between levels and CC offerings:
A brief description of these competency development offerings is given below:

Train The Trainer Program:

Is an enablement program for faculty members on any of the cutting edge technology topics or on any relevant soft skills areas. The program duration would vary from three to five days and will be conducted either at Infosys Development Centres or at any of the identified Campus Connect partnering institutions in the region.

Paper Publication Sponsorships:

Paper Publication Sponsorship activity provides opportunity for partner college faculty members to:

Showcase their publications

Sharing knowledge with academia and Industry

Provides opportunity to get sponsorship from Infosys for registration fee towards paper presentation

Sabbaticals:

Sabbaticals are an opportunity for Campus Connect partner college faculty members to work with project units at Infosys development centres and get exposed to software development methodologies and practices at Infosys. Typical duration of would be 6 to 8 weeks full time and faculty members would be selected after an interview with the concerned project team. Participating faculty members will receive remuneration for their contribution to project.

The project deliverables may include one or more from:

\section{Working Prototype / Proof of concept}

2. Design to develop a system/application

3. Analysis of existing systems/applications

4. Literature survey

\section{Research Support:}

Faculty members who are pursuing their PG or $\mathrm{Ph} . D$. programs may avail assistance from Infosys for their research. Infosys can support by conducting research methodology workshops. This can also include research guidance from Infosys experts and opportunity to partner for research activities with Infosys. 
Co-publishing in journals / magazines:

Faculty members can partner with Infosys experts for writing articles and papers in areas related to Information Technology in reputed journals and magazines. Interested faculty would share the theme of the paper/article and CC SPoC would connect with pertinent SMEs in Infosys. This would help both faculty and Infosys member to supplement each other's knowledge and bring out a comprehensive view on the topic.

Aspirations 2020:

Infosys conducts Aspirations2020 Programming contest for Engineering and MCA students every year. This is organized by Campus Connect team of Infosys and sponsored by Infosys Limited. Aspirations2020 is a platform for students to prepare themselves to become smart professionals. Aspirations2020 will encourage the spirit of competitiveness and accelerate learning through extra- curricular activities, within the student community. This is an extremely important event which will help students to foster problem solving and algorithmic thinking abilities. Aspirations 2020 is based on internet technology assisted online Programming Contest.

\section{Our College Data For The Past Three Years}

Table 1 - Recruitment Data

\begin{tabular}{|l|l|l|l|}
\hline Year & $\begin{array}{l}\text { Offers to } \\
\text { tested ratio }\end{array}$ & $\begin{array}{l}\text { Contribution } \\
\text { Score }\end{array}$ & Remarks \\
\hline $\begin{array}{l}2014- \\
15\end{array}$ & $59 \%$ & $11.7 \%$ & $\begin{array}{l}\text { The corresponding } \\
\text { scores for the Top } \\
\text { Performers in the } \\
\text { region are 59\% and } \\
11.7 \% \text { respectively }\end{array}$ \\
\hline $\begin{array}{l}2013- \\
14\end{array}$ & $57 \%$ & $8.24 \%$ & $\begin{array}{l}\text { The corresponding } \\
\text { score for the Top } \\
\text { Performing CC college } \\
\text { in the region is 57\% } \\
\text { and 15.81\% respectively }\end{array}$ \\
\hline $2012-$ & $38 \%$ & $10 \%$ & $\begin{array}{l}\text { The corresponding } \\
\text { scores for the Top } \\
\text { Performers in the } \\
\text { region are 45\% and } \\
\text { 25\% respectively }\end{array}$ \\
\hline
\end{tabular}

Table 1 shows the Infosys Recruitment Data from our college [2]. The Offers to Tested Ratio indicates the no. of offers made for every 100 tested students. For example, in 2014-15, for every 100 tested students, offers have been made for 59 students. The
Contribution Score indicates, our college contribution to the overall recruitment of that year. For example, in 2014-15, our college contribution to overall Infosys recruitment is $11.7 \%$. In 2014-15, Infosys has recruited 3000+ students from 92 colleges located in Karnataka and Tamil Nadu. Out of these, 331 are from our college and our college is the top performer.

Table 2 - Elective Type Signed Off (BoS)

\begin{tabular}{|c|c|c|c|c|c|c|c|c|}
\hline Yr. & $\begin{array}{l}\mathrm{Bu} \\
\text { sin } \\
\text { ess } \\
\text { Int } \\
\text { elli } \\
\text { gen } \\
\text { ce }\end{array}$ & $\begin{array}{l}\text { Ent } \\
\text { erp } \\
\text { rise } \\
\text { Ap } \\
\text { plic } \\
\text { atio } \\
\text { ns }\end{array}$ & $\begin{array}{l}\text { Fou } \\
\text { nda } \\
\text { tion } \\
\text { Pro } \\
\text { gra } \\
\text { m }\end{array}$ & $\begin{array}{l}\text { Aer } \\
\text { osp } \\
\text { ace } \\
\text { En } \\
\text { gin } \\
\text { eeri } \\
\text { ng }\end{array}$ & $\begin{array}{l}\text { We } \\
b \\
\text { Tec } \\
\text { hno } \\
\text { logi } \\
\text { es }\end{array}$ & $\begin{array}{l}\text { Mo } \\
\text { bile } \\
\text { Ap } \\
\text { ps }\end{array}$ & $\begin{array}{l}\text { Oth } \\
\text { er }\end{array}$ & $\begin{array}{l}\text { Tot } \\
\text { al }\end{array}$ \\
\hline $14-15$ & 2 & 1 & 1 & 2 & 1 & 2 & 1 & 10 \\
\hline $13-14$ & 2 & 1 & 1 & 2 & 0 & 1 & 0 & 7 \\
\hline $12-13$ & 2 & 1 & 1 & 2 & 0 & 0 & 0 & 6 \\
\hline
\end{tabular}

Table 2 shows the number of electives signed off with Infosys [2]. Our college has signed and offering a number of electives in the domains of Business Intelligence, Building Enterprise Applications, Aerospace Engineering, Web Technologies, Mobile Application Development etc. The last column in the above table indicates total number of electives.

Table 3 - Technical Elective Summary

\begin{tabular}{|l|l|l|l|}
\hline Year & $\begin{array}{l}\text { No. of } \\
\text { batches }\end{array}$ & $\begin{array}{l}\text { No. of } \\
\text { students } \\
\text { trained }\end{array}$ & Elective Name \\
\hline $\begin{array}{l}2014- \\
15\end{array}$ & 13 & 1366 & $\begin{array}{l}\text { EIT, Introduction to } \\
\text { Aircraft Industry \& Aircraft } \\
\text { Sys, MAD, BIA, C\# and } \\
\text {.NET, Web Programming }\end{array}$ \\
\hline $\begin{array}{l}\text {-N13- } \\
14\end{array}$ & 9 & 874 & $\begin{array}{l}\text { EIT, Introduction to } \\
\text { Aircraft Industry \& Aircraft } \\
\text { Sys, MAD, BIA, C\# and } \\
\text { NET, Web Programming }\end{array}$ \\
\hline $2012-$ & 6 & 785 & $\begin{array}{l}\text { EIT, Introduction to } \\
\text { Aircraft Industry \& Aircraft } \\
\text { Sys, BIA }\end{array}$ \\
\hline
\end{tabular}

3 shows the Technical Elective Summary [2]. For example, in 2014-15, nearly 13 batches of students numbering about 1366 have undergone various electives mentioned in the last column. You can see 
every year the number of batches, number of students and number of electives keep on increasing.

Table 4 - Event Participation

\begin{tabular}{|l|l|l|}
\hline Year & $\begin{array}{l}\text { No. FEP/ TTT } \\
\text { (Technical) Participated }\end{array}$ & $\begin{array}{l}\text { \# Faculty Participated } \\
\text { (FEP/ TTT) }\end{array}$ \\
\hline $2014-15$ & 2 & 12 \\
\hline $13-14$ & 3 & 33 \\
\hline $12-13$ & 3 & 23 \\
\hline
\end{tabular}

Table 4 gives the data about various Event Participation by our faculty [2]. For example, during 2014-15, two Faculty Enablement Programme or Train The Trainer workshop have been conducted in our college, wherein 12 of our faculty members have participated. We also include faculty from nearby colleges. This data is not shown in the table.

Table 5 Contest Participation faculty and students

\begin{tabular}{|l|l|l|l|l|}
\hline Year & $\begin{array}{l}\text { \#Teams } \\
\text { Registered } \\
\text { for ASP202 }\end{array}$ & $\begin{array}{l}\text { \#Teams } \\
\text { participated } \\
\text { in ASP2020 } \\
\text { DC Finals }\end{array}$ & $\begin{array}{l}\text { \#Teams } \\
\text { registered } \\
\text { for Inspire } \\
\text { Excellence } \\
\text { Award }\end{array}$ & $\begin{array}{l}\text { \#Teams } \\
\text { participated } \\
\text { in Annual } \\
\text { Inspire } \\
\text { Excellence } \\
\text { Award Event }\end{array}$ \\
\hline $\begin{array}{l}2014- \\
15\end{array}$ & 63 & 0 & 0 & 0 \\
\hline $\begin{array}{l}2013- \\
14\end{array}$ & 57 & 0 & 1 & 1 \\
\hline $\begin{array}{l}2012- \\
13\end{array}$ & 80 & 0 & 0 & 0 \\
\hline
\end{tabular}

Table 5 indicates various Contest Participation by our faculty and students [2]. For example, during 201314,57 students from our college participated in the Aspirations 2020 Programming Contest. One team of faculty registered and participated in the Annual Inspire Excellence Award Event conducted at Infosys DC, Mangalore.

Table 6 - Inspire Partnership Level

\begin{tabular}{|l|l|l|l|l|}
\hline Year & $\begin{array}{l}\text { \#Faculty } \\
\text { nominated } \\
\text { for Inspire } \\
\text { Partnership } \\
\text { Level }\end{array}$ & $\begin{array}{l}\text { \#Faculty } \\
\text { certified } \\
\text { for Bronze } \\
\text { partnership }\end{array}$ & $\begin{array}{l}\text { \#Faculty } \\
\text { certified } \\
\text { for Silver } \\
\text { partnership }\end{array}$ & $\begin{array}{l}\text { \#Faculty } \\
\text { certified } \\
\text { for Gold } \\
\text { partnership }\end{array}$ \\
\hline $\begin{array}{l}2014- \\
15\end{array}$ & 1 & 1 & 1 & 0 \\
\hline $2013-$ \\
14
\end{tabular}

Based on the contribution of our faculty members towards Campus Connect programme, Infosys recognizes faculty as Gold, Silver and Bronze Level partner. The contributions are in the form of offering electives, conducting workshops and designing innovative projects. Table 6 shows the number of faculty certified for Bronze, Silver or Gold Partnership Leve1 [2].

Table 7 - Infosys Training Performance Legends

\begin{tabular}{|l|l|l|l|}
\hline $\begin{array}{l}\text { TP }- \text { Top } \\
\text { Performers }\end{array}$ & A+ Grade & out of 100 & Marks $>=92$ \\
\hline $\begin{array}{l}\text { HP }- \text { High } \\
\text { Performers }\end{array}$ & A Grade & out of 100 & $\begin{array}{l}\text { Marks }>=80 \\
\text { and }<92\end{array}$ \\
\hline $\begin{array}{l}\text { AAP - Above } \\
\text { Average } \\
\text { Performers }\end{array}$ & B+ Grade & out of 100 & $\begin{array}{l}\text { Marks }>=70 \\
\text { and }<80\end{array}$ \\
\hline $\begin{array}{l}\text { AP - Average } \\
\text { Performance }\end{array}$ & B- Grade & out of 100 & $\begin{array}{l}\text { Marks }>=65 \\
\text { and }<70\end{array}$ \\
\hline $\begin{array}{l}\text { PP - Poor } \\
\text { Performers }\end{array}$ & C Grade & out 100 & Marks $<65$ \\
\hline
\end{tabular}

Table 7 shows the Legends $(\mathrm{A}+, \mathrm{A}, \mathrm{B}+, \mathrm{B}$ and $\mathrm{C}$ grades) for various categories of performers.

Table 8 - Performance Data

\begin{tabular}{|l|l|l|l|l|l|l|}
\hline Year & $\begin{array}{l}\text { TP } \\
\text { HP } \%\end{array}$ & & AAP+AP\% & & PP\% & \\
\hline & CS & NCS & CS & NCS & CS & NCS \\
\hline $\begin{array}{l}2014- \\
15\end{array}$ & $14 \%$ & $13 \%$ & $25 \%$ & $43 \%$ & $3 \%$ & $2 \%$ \\
\hline $\begin{array}{l}2013- \\
14\end{array}$ & $17 \%$ & $32 \%$ & $14 \%$ & $25 \%$ & $3 \%$ & $7 \%$ \\
\hline $\begin{array}{l}2012- \\
13\end{array}$ & $13 \%$ & & $80 \%$ & & $7 \%$ & \\
\hline
\end{tabular}

In Table 8, CS indicates Computer Science (CS and IS) students and NCS indicates Non-Computer Science students (Civil, Mechanical, EEE, ECE \& BT) [2]. After our students join Infosys, there will be Performance Evaluation after six months. The above data shows their Performance Level. For example, in $2014-15,14 \%$ of CS \& $13 \%$ of NCS were TP $+\mathrm{HP}$, $25 \%$ of CS \& $43 \%$ of NCS were AAP $+\mathrm{AP}$ and $3 \%$ of $\mathrm{CS}$ and $2 \%$ of NCS were PP.

\section{Benefits Obtained And Looking Forward}

The current status of Industry-Academia 
interaction with Infosys at NMAMIT is very encouraging [3] and show lot of potential for further interaction. The interaction has helped the institute in providing current curriculum to the students, providing additional training and skills to enhance their employability, providing additional training to the faculty and supporting their R \& D activities and providing readily employable students to the industries. This interaction has further strengthened the efforts of the faculty in getting significant research funding from government funding agencies and also from many leading industries and organizations. There has been a significant increase in publications in leading international journal and conference proceedings [4]. Additional benefit of this interaction has been in community development, helping local students and industries, from the knowledge gained through this interaction. Significant intellectual property has been generated both by the institution and the industry helping in the development of future technology.

\section{Conclusion}

This paper provides an overview about the current status of industry partnerships with Infosys for promoting effective teaching and learning experience to students of NMAMIT. The efforts has been mutually rewarding to both the Institution and the industry, with significant improvements in curriculum, training inputs, project work, R \& D outputs, publications / patents and placements, to both students and faculty. Overall there has been increase in employability skills \&intellectual outputs, which will contribute to the overall growth and development of the Institution and the Industry.

\section{References}

[1] Infosys Campus Connect Portal ( www.campusconnect.infosys.com)

[2] College Data Sheets provided by Infosys

[3] SrinivasaPai. P, Niranjan N Chiplunkar., "Success Story of Industry Institution Collaboration for Enhancing Teaching Learning Experience", International Conference on Transformation in Engineering Education (ICTIEE 2014) held from 16th to 18th January 2014 at BVB College of Engineering and Technology, Hubli .

[4] Pai, S.P, Bhat, K.S., Sriram N.S., \&Samaga, B. S., "Increased Industry-Academia Interaction and its Relevance for Technological Innovation in the New Globalized world", Souvenir of 37th Annual ISTE Convention \& National Seminar on Excellence in Technical Education through Innovation at MIT, Manipal, Dec 17-19, 2007, pp 44. 